\title{
THE ESSENCE OF EVALUATION OF THE CRISIS RESPONSE OPERATION
}

\author{
Marta OSYPOWICZ, M.A.
}

National Defense University, Warsaw, Poland

\begin{abstract}
Crisis response operations (CROs) become the universal means used to solve a crisis situation. Their goal is preventing a potential conflict, responding and removing the effects of conflict and restoring pre-crisis situations. A wide range of these operations can be used in response to various crisis situations: natural disasters or armed conflicts. All of these factors and their flexibility speak for their effectiveness. Therefore, the number of publications about CROs is still increasing. Usually, the experts try to establish why operations were successful or failed but don't explain how an assessment was accomplished. The observed properties of the theory indicate the biggest gaps in the evaluation of CROs. Noticing a gap led the author to conduct research on the evaluation of the CROs, some of which are presented in this article.
\end{abstract}

Keywords: crisis response operation, evaluation, criteria, matrix, successful, failure.

A crisis response operation belongs to a group of military measures which are generally used in crisis situations. The main goal of this measure is to prevent probable conflicts or to respond and deal with the effects of an ensuing crisis situation. An available range of operations allows them to be used to remove different threats, e.g. those caused by nature (a natural disaster) or by human beings (military conflicts). Taking into account the broad spectrum of the impact of these, it seems be a fair statement that crisis response operations are an effective measure to prevent and respond. As a consequence, the number of operations is still increasing as is the number of publications about them. 
When talking about crisis response operations, it should be noted that most authors are limited to determining whether the operation was a success or a failure or highlighting the course of a taken action without clarifying how the presented results were achieved. It has been suggested that the biggest wastages are in the evaluation ${ }^{1}$ of crisis response operations. A noticeable wastage led the author to conduct, as part of a doctoral dissertation, an evaluation of selected crisis response operations that were used to outline a prognosis of future NATO crisis response operations in their organisation and their probable course.

In this article, the author would like to present part of her own research focusing on: the essence of crisis response operations and the evaluation process, and a description of methods used to select criteria and tools used in the evaluation of selected operations. Considering the issues discussed, the goal of these considerations will be to carry out evaluation of a selected crisis response operation by using a specific tool. The expected results of this research will be achieved by answering the general question: to what extent (range) can the tools used for evaluation enable a reliable analysis and assessment of a selected crisis response operation? In order to clarify the general problem, the following specific issues should be clearly explained: 1 ) What is the nature of crisis response operations?; 2) What is the nature of the evaluation?; 3) what methods were used in the process of selection criteria to conduct an evaluation?; 4) How was the course of the evaluation process of the allied Unified Protector crisis response operation in Libya?

\section{The nature of the crisis response operations}

The essence of crisis response operations comes from their main goal: prevent, respond to and remove the effects of possible crisis situations. The operations of this type are carried out by the multinational division performing a mission under the auspices of one of the international organisations (ex. NATO, EU or UN) or

1 In this study, the evaluation will be understood as an analysis that collects the data necessary for appraisal. This assessment will be considered an evaluative judgment or sentence, expressing approval or disapproval. Note the author. 
one of the participating countries (the so called lead state), in collaboration with various political, economic and humanitarian organisations.

Considering the goal of an action, crisis response operations can be divided into crisis response operations in accordance with article 5 of the North Atlantic Treaty (CRO) and Non-Article 5 crisis response operations (NA5CRO). The Non-Article $5 \mathrm{CRO}$ share in the peace support operations (Figure 1) and the other (Figure 2).

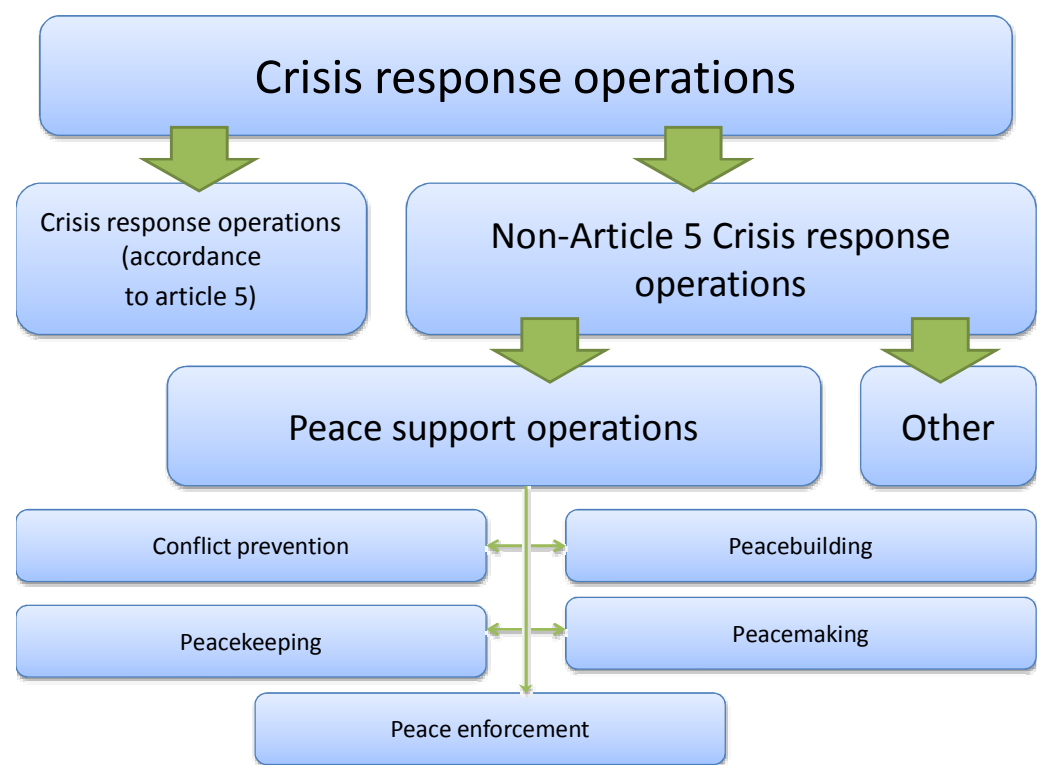

Source: own.

Figure 1. The classification of NATO crisis response operations

The crisis response operations conducted according to Article 5 of the North Atlantic Treaty, according to the Allied Joint Doctrine for Non-Article 5 Crisis Response Operations (AJP 3.4.), serve to ensure a collective defence arising from the content of this article ${ }^{2}$. The Non-article 5 crisis response operations,

2 The Parties agree that an armed attack against one or more of them in Europe or North America shall be considered an attack against them all; and consequently they agree that, if such an armed attack occurs, each of them, in exercise of their right of individual or collective self-defence recognized by Article 51 of the Charter of the United Nations, will assist the Party of Parties so attacked by taking forthwith, individually and in concert with the other Parties, such action as it deems necessary, including the use of armed force, to restore and maintain the security of the North Atlantic area; North Atlantic Treaty, Washington 4 April 1949, art. 5. 
according to AJP 3.4., are designed to respond to a crisis situation which can have an influence on the security of the NATO member countries or if this situation threatens NATO stability ${ }^{3}$.

The characteristics attributed to these activities: flexibility, speed and correct precision, can generally be observed as the means used to prevent and respond to various crisis response operations. An awareness of the possibility of using them means that safety between the member states and partners is increased and the level of protection of individual countries interests and the organisation as a whole is increased.

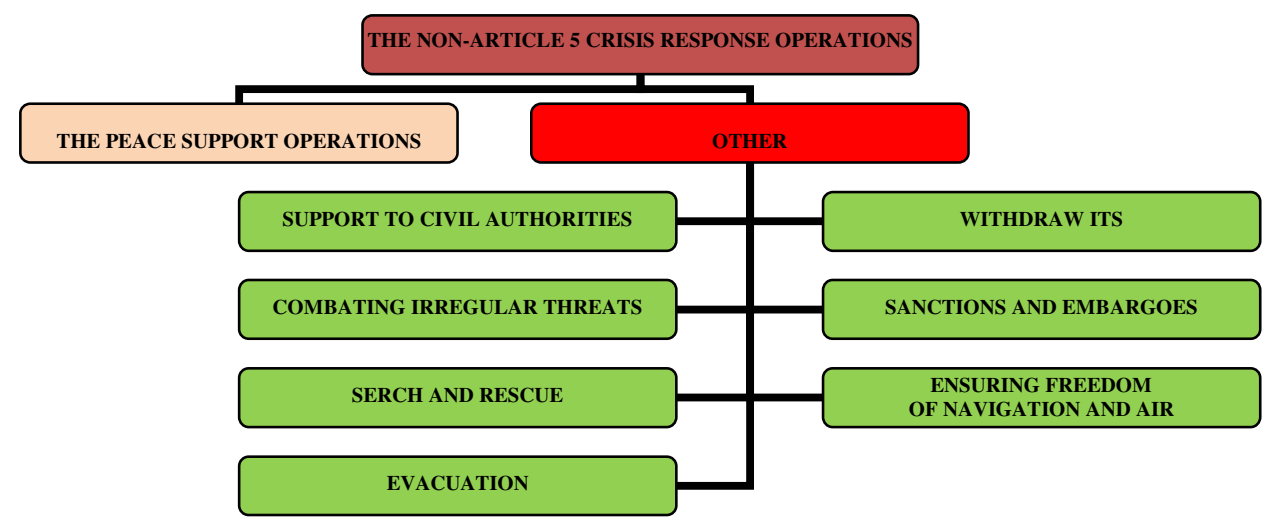

Source: own.

Figure 2. The classification of other Non- Article 5 crisis response operations

The process of preparing and conducting an operation is determined by a variety of conditions and factors, which include: historical and political conditions prevailing in a theatre of action and operational factors, contextual factors and behavioural factors.

Among the political conditions, particular attention should be given to: compatibility of the goal of operations with the interests and goals of the organisation or coalition of states conducting them; analysis of the capabilities (e.g. economic, military) of the country from the perspective of the time required to

3 See in: Allied Joint Publication 3.4., Non-Article 5 Crisis Response Operations, NATO/ NAS Brussels 2005, p. $1-1$. 
achieve the end state of operations (short-term or long-term) ${ }^{4}$; and the legal basis of these operations. Attention should also be drawn to the historical conditions prevailing in a conflict zone, because if we learn about history, causes and the essence of a conflict situation it makes our chance of achieving an end state of this operation more likely.

Among the determinants of the planning process of a crisis response operation we can also identify operational factors, contextual factors and behavioural factors ${ }^{5}$. The operational factors, i.e. the mandate of operation, the potential and the organisational structure (national, multinational and coalition) and the tactic of operations, contribute to the effective conduct of multinational forces and to effective implementation of tasks by national contingents. The contextual factors, i.e. the kind of war and geography (topography and population density) mean that the security of multinational forces is increased. The last group of factors is behavioural factors, which concern the rules of the conduct of actors involved in a conflict. Included among them: the primary disputants and third-party states (neighbours, major powers and subnational actors). We should also concentrate on actions taken by these actors because this can have a positive or negative influence on activities carried out by multinational forces.

\section{The nature of evaluations and its classification}

The evaluations of foregoing crisis response operations can effectively process the preparing and conducting of future crisis response operations. According to the Polish Evaluation Society, an evaluation is defined "as an assessment of the value of a project with the use of specific criteria to improve it, develop it or better understand it" or as "taking, analysing and interpreting data about the

4 Seein:M.Bieniek, Kategorieoperacjipokojowych.Czynniki wptywajacenazaangażowanie Polski w operacje pokojowe, [w:] E. Trela - Mazur (red.), Problemy bezpieczeństwa wspótczesnego świata, Uniwersytet Opolski, Opole 2009, p. 117.

5 See in: M. Osypowicz, The use of crisis response operation in NATO crisis management system; Second International Conference of Young Security Policy Experts; edited by: Dr. Jozsef Lajos NEMETH, Ph.D.; Publisher: Association of the Advanced College for Security Policy National University of Public Service HUNGARY, Budapest, ISBN 978-615-5305-11-5. 
value of a project to point out issues important to the stakeholders ${ }^{6}$. To quote L. Krzyzanowski, the assessment (evaluation) of crisis response operations can be perceived as a "value judgment [...] any statement expressing a positive or negative attitude of an evaluator to a subject of evaluation"7, during which an evaluator can be found as an individual or a group of people or international organisations ${ }^{8}$. In a situation where we prepare an evaluation of a crisis response operation, an evaluator can be a soldier who took part in that operation or a theorist dealing with the issue or a representative of an international organisation responsible for the preparing and conducting of undertaken actions ${ }^{9}$. The subject of an evaluation can be both real and conceptual components of reality, $(. . .)^{10}$, which involved: qualities of things (person), a collection of these qualities, i.e. state of things (personality); changes of these states, i.e. process (behavioural, action); events, i.e. culminating results of this process (facts, as events which are a result of human activities); relations, i.e. a relationship and interaction which occurs between: things (peoples), states of affairs, process and the events ${ }^{11}$. During the conducting of an effective evaluation of crisis response operations we can choose a different subject of this process. For example, a subject of this process can be an organisational structure of a multinational force or the hierarchical relationship between the elements forming these structures.

There are different classifications of evaluation, e.g. a standard evaluation ${ }^{12}$ and a utilitarian evaluation ${ }^{13}$. Considering the quantitative criterion, it can be

6 http://www.pte.org.pl/x.php/1,155/O-ewaluacji.html (data pobrania: 06.04.2011 r.)

7 L.J. Krzyżanowski, O podstawach kierowania organizacjami inaczej: paradygmaty, modele, metafory, filozofia, metodologia, dylematy, trendy, Wydawnictwo Naukowe PWN, Warszawa 1999, p. 204.

8 See in: M. Osypowicz, I. Denysiuk, Istota $i$ założenia oceny operacji reagowania kryzysowego [w:] M. Kopczewski, I. Grzelczak-Miłoś, M. Walachowska, Paradygmaty badań nad bezpieczeństwem. Zarzadzanie kryzysowe w teorii i praktyce, Wydawnictwo Wyższej Szkoły Bezpieczeństwa, Poznań 2013, p. 130.

9 See in: Ibidem, p. 130.

10 L. J. Krzyżanowski, O podstawach kierowania..., op. cit., p. 204.

11 Ibidem, p. 204-205.

12 The standard evaluation - concern of the internal values of the system, on that basis we predicate that the system is necessarily simply good or bad, or that something is the goal of the proceedings; P. Sienkiewicz, Teoria efektywności systemów, Wydawnictwo Polskiej Akademii Nauk, Wrocław, Warszawa, Kraków, Gdańsk, Łódź, 1987, p. 32.

13 The utilitarian evaluation - concern of the external values of the system, on the basis of which we can decide that a system is good or bad because of something or that something is the means to something else; Ibidem, p. 32. 
distinguished as a single- ${ }^{14}$ and multi-criteria ${ }^{15}$ evaluation. Taking into account the evaluator criterion, it can be distinguished as an individual or group (collective) evaluation ${ }^{16}$. In the case of evaluation of crisis response operations, one of two assessments that can be used favours a time criterion (Figure 3): a retrospective evaluation (ex post) or a prospective evaluation (ex ante $)^{17}$.

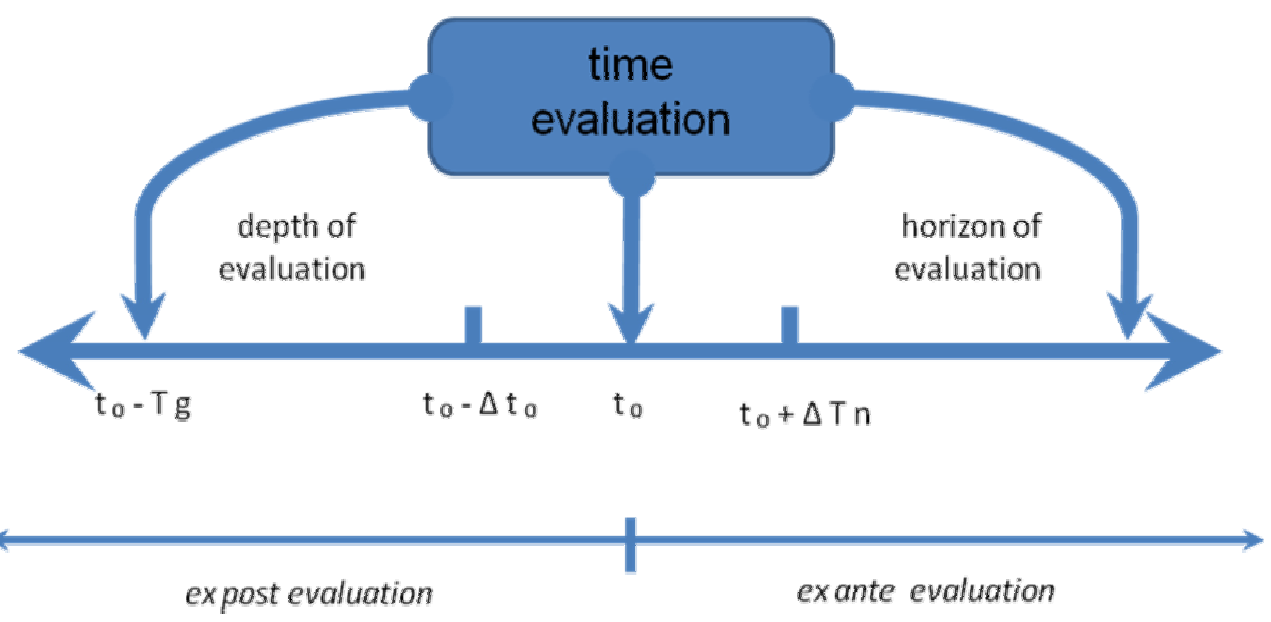

Source: own by the P. Sienkiewicz, Teoria efektywności systemów, Wydawnictwo Polskiej Akademii Nauk, Wrocław, Warszawa, Kraków, Gdańsk, Łódź, 1987, s. 32.

Figure 3. The classification of evaluation by the time criterion

A retrospective evaluation is "an assessment formulated for the past states of a subject of the assessment (in relation to the time when the assessment is carried out [ $\mathrm{t}_{0}$ - added by author] ${ }^{\prime 18}$. In particular, an evaluation of this type is proved in the case of a military action (war), when the two fighting parties are regular armed forces whose potential is similar in quantity and quality. If you use them in an evaluation of a crisis response operation, we come up against a multitude of problems. Firstly, these operations are characterised by a volatility,

14 The single-criteria evaluation - the assessment is formulated based on one and only one criteria of evaluation; Ibidem, p. 33.

15 The multi-criteria evaluation - the assessment is formulated based on a minimum two criteria of evaluation; Ibidem, p. 33.

16 See in: Ibidem, p. 33.

17 See in: Ibidem, p. 32.

18 Ibidem, p. 32. 
multidimensionality and dimensionality of actions. Secondly, by the ratio of fighting parties in a quantitative and qualitative respect. In the case of operations, we have a regular force (division army or coalition of states) leading action against an irregular force (ex. guerrillas or insurgents). It should also be noted that multinational forces are military units which have received military training. However, guerrillas (insurgents) are unmilitary units without military training. Their motivation to take part in this war is a religious one or has a historical precedent (revenge). Consideration of these differences should be applied to the selection of appropriate criteria and, in consequence, an effective evaluation of these activities can be made.

The next type of evaluation is a prospective evaluation, which P. Sienkiewicz defined as "an assessment formulated for the future states of a subject of an assessment (in relation to the time when an assessment is carried out [ $\mathrm{t}_{0}$ - added by author])"19. This type of evaluation played an important role in the decision-making process of preparing and conducting a crisis response operation ${ }^{20}$. Keep in mind that the prospective evaluation is based on a retrospective evaluation ${ }^{21}$. Considering the possibilities arising from using this, it should be noted that, correctly implemented, the ex post evaluation process will contribute to avoiding many problems in a complex, as considered by M. Marszalek, a prori evaluation process ${ }^{22}$.

\section{The process of selecting criteria for an evaluation of a crisis response operation}

A substantive evaluation of a crisis response operation, based on a detailed analysis of collected information, will contribute to modifying the process of preparing and conducting a future operation. "An evaluation of operation should be a sum

19 Ibidem, p. 33.

20 See in: M. Marszałek, Interwencja humanitarna - typologia, kryteria sukcesu, „Zeszyty Naukowe AON", nr 3(76)/2009, p. 66.

21 See in: P. Sienkiewicz, Teoria ..., op. cit., p. 33.

22 See in: M. Marszałek, Dylematy ewaluacji operacji wsparcia pokoju [w:] P. Sienkiewicz, M. Marszałek, H. Świeboda (red. nauk.), Metodologia badań bezpieczeństwa narodowego. Bezpieczeństwo 2010, t. II, AON, Warszawa 2011, p. 199. 
of all the elements, should be a calculated assessment of reality (past), effected on both at assessment of strategic and operational plans ${ }^{23}$. However, if we want that this process go smoothly, it should be based on analysis of collected material in terms of generated criteria.

In order to prepare an evaluation of choosing a crisis response operation, the author chose criteria based on an organisational approach based on the Leavitt model. This model presents an organisation as a collection of four elements (subsystems): goals and tasks, people, structure, technique and technology, between are relationships known as „interactions” or „dependency” or connections (... $)^{24}$. Additionally, during the process of selection criteria for evaluation, operational factors are also taken into account, which include: a mandate (mission and goals), an organisational structure, the potential and tactics of activities. Detailed analysis of these factors and using an organisational approach contributed to the selection of the following criteria: mission and goals (a mandate), a concept, an organisational structure and potential, tactics.

As part of the process of generating criteria to prepare an evaluation of crisis response operations, these questions have been raised:

1. Have the end states (mission and goals) of a crisis response operation been achieved?

2. Has a concept of the activities carried out in the operation been effectively and efficiently applied to a situation?

3. Has the organisational structure and potential used in the operation been adequate for its activities?

4. Have the tactics used in this operation contributed to the end states of an operation?

These general questions, which are crucial to the proper conducting of an evaluation process, are included in an evaluation matrix of a crisis response operation (Table 1). Each of these general criteria has been further divided into sub-criteria whose goal is to facilitate the process of obtaining answers expressing the positive or

23 See in: I. Denysiuk, M. Osypowicz, Istota i założenia operacji reagowania kryzysowego, op. cit., p. 127.

24 L.J. Krzyżanowski, O podstawach kierowania ..., op. cit., p. 29. 
negative attitude of an evaluator to the subject of assessment ${ }^{25}$. In the context of these considerations, an evaluator was considered to be a representative dealing with NATO crisis response operations and NATO crisis management issues and a matter of evaluation, was considered an allied Unified Protector crisis response operation in Libya or an organisational aspect and conduct.

\begin{tabular}{|c|c|c|c|}
\hline \multirow{2}{*}{$\begin{array}{l}\text { ANALYSIS } \\
\text { the generation criteria }\end{array}$} & \multicolumn{2}{|c|}{ INDEPENDENT VARIABLE } & \multirow{2}{*}{$\begin{array}{l}\text { DEPENDENT } \\
\text { VARIABLE } \\
\text { result }\end{array}$} \\
\hline & sub-criteria & value & \\
\hline \multirow{3}{*}{$\begin{array}{l}\text { Have end states (mission } \\
\text { and goals) of a crisis } \\
\text { response operation been } \\
\text { achieved? }\end{array}$} & legitimacy & YES/NO & \multirow[b]{3}{*}{ YES/NO } \\
\hline & mission of operation & YES/NO & \\
\hline & $\begin{array}{l}\text { goal of operation } \\
\text { (political, military, } \\
\text { humanitarian) } \\
\end{array}$ & YES/NO & \\
\hline \multirow{2}{*}{$\begin{array}{l}\text { Has a concept of } \\
\text { activities carried out } \\
\text { in operation been } \\
\text { effectively and efficiently } \\
\text { applied to a situation? } \\
\end{array}$} & planning process & YES/NO & \multirow{2}{*}{ YES/NO } \\
\hline & selection of component & YES/NO & \\
\hline \multirow{3}{*}{$\begin{array}{l}\text { Have an organisational } \\
\text { structure and potential } \\
\text { used in operation } \\
\text { been adequate for its } \\
\text { activities? }\end{array}$} & organisational structure & YES/NO & \multirow{3}{*}{ YES/NO } \\
\hline & potential & YES/NO & \\
\hline & targeting & YES/NO & \\
\hline \multirow{2}{*}{$\begin{array}{l}\text { Have tactics used in this } \\
\text { operation contributed } \\
\text { to the end states of an } \\
\text { operation? }\end{array}$} & effectiveness & YES/NO & \multirow[b]{2}{*}{ YES/NO } \\
\hline & mileage (phases) & YES/NO & \\
\hline
\end{tabular}

Source: own.

Table 1. The evaluation matrix of the crisis response operations

\section{An evaluation of an allied Unified Protector crisis response operation in Libya}

An allied Unified Protector crisis response operation is considered to be a model instance of an operation conducted by NATO. In this operation, an air component, sea component and a special force cooperated together and with Libyan rebels in

25 See in: L. J. Krzyżanowski, O podstawach kierowania ..., op. cit., p. 204. 
order to achieve its goals. This was also an example of an action during which the latest generation of military potential was used, so consequently contributed to reducing the loss of their own and the civilian population to a minimum.

In Africa, poverty and unemployment generally predominate. This situation and a political system based on dictatorship, which is dominant in African countries, initiated a series of protests in the Arab world in 2010 (Figure 4). In Tunisia, on 17 December 2010, a street vendor set light to himself in public as a protest against the government. In Egypt, on 21 January 2011, the civilian population started ongoing demonstrations to overthrow the State President H. Mubarak (19 February 2011). In contrast to the neighboring countries, a demonstration in Libya escalated into a military conflict between Libyan partisans and forces loyal to M. Gaddafi ${ }^{26}$, who had been ruling for over 41 years. The President of Libya used a repressive policy against its citizens. The international community reaction was immediate. The United Nations in cooperation with the African Union and the Arab League condemned the methods used by Gaddafi and took diplomatic and military measures to deal with this conflict.

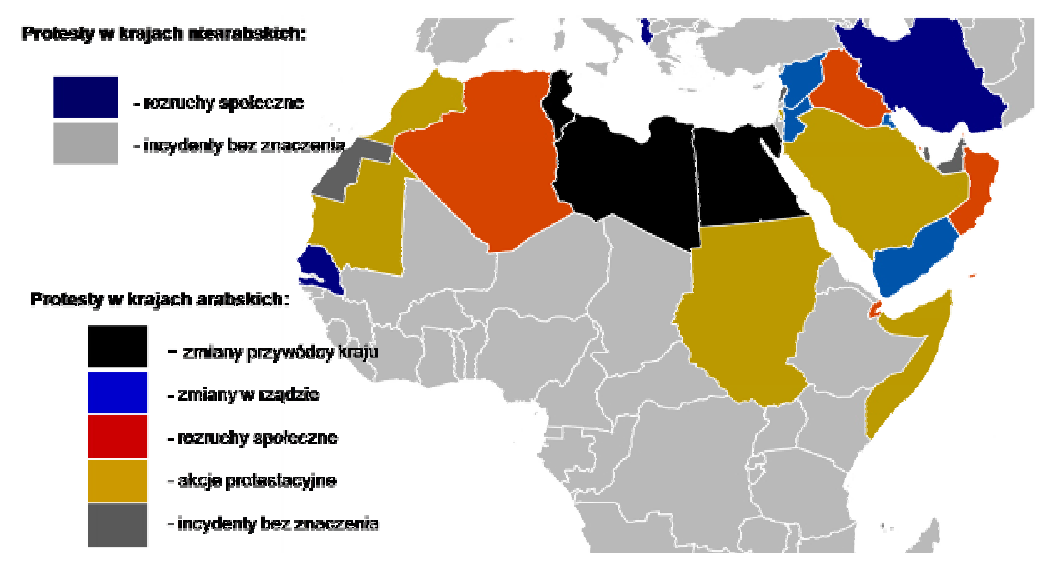

Source: own based on http:/pl.wikinews.org/wiki/Plik:2010-2011_Arab_world_protests.svg (12.02.2013 r.)

Figure 4. The Arab Spring 2010 - 2011

26 D. Brążkiewicz, Wojna domowa w Libii w 2011 roku, KWARTALNIK BELLONA, Ministerstwo Obrony Narodowej, Rocznik XCIV (VI), Nr 4/2012 (671), Warszawa 2012, p. 140. 
On 26 February 2011, the UN Secretary Council adopted Resolution No. 1970 expressing concern about a growing conflict in Libya. The international community decided to impose an embargo on arms supplies to this country ${ }^{27}$. The measures applied did not bring the expected results, so the UN Security Council adopted a further Resolution 1973 on 17 March 2011 expressing grave concern at the deteriorating situation, the escalation of violence, and the heavy civilian casualties; reiterating the responsibility of the Libyan authorities to protect the Libyan population and reaffirming that parties to armed conflicts bear the primary responsibility to take all feasible steps to ensure the protection of civilians; condemning the gross and systematic violation of human rights, including arbitrary detentions, enforced disappearances, torture and summary executions ${ }^{28}$ and granting an authorisation for Member States to use all available means, without excluding use of armed violence, in order to: 1) ensure safety and protection to civilians and humanitarian organisations, 2) establishment and enforcement of a no-fly zone over Libya, and 3) compliance with the arms embargo to that country $^{29}$. This Resolution was a mandate and legitimised international actions against the regime of Gaddafi. With approval of the international community, a coalition of countries (United States, United Kingdom and France) started an Odyssey Down ${ }^{30}$ operation, which was replaced by an allied Unified Protector operation on 31 March $2011^{31}$.

As part of the evaluation process of the allied Unified Protector crisis response operation in Libya, the author made a detailed analysis of collective material based on the following criteria: mission and goals (end state), a concept, an organisational structure and potential and applied tactics. In order to effectively conduct this process, the author used an evaluation matrix (Table 2).

27 See in: UN Security Council Resolution 1970 (2011), adopted by the Security Council at its 6491th meeting, on 26 February 2011, S/RES/1970 (2011).

28 See in: Ibidem.

29 See in: Ibidem.

30 The coalition operation Odyssey Down aimed to enforce the no-fly zone over Libya. This operation was an air operation. Britain, France and the United States armed forces took part in it. Note the author.

31 The allied Unified Protector crisis response operation was conducted in accordance with Chapter 7 of the Charter of the United Nations dedicated to take action in an emergency regarding peace, breaches of the peace and acts of aggression. Note the author. 


\begin{tabular}{|c|c|c|c|}
\hline \multirow{2}{*}{$\begin{array}{l}\text { ANALYSIS } \\
\text { the generation criteria }\end{array}$} & \multicolumn{2}{|c|}{ INDEPENDENT VARIABLE } & \multirow{2}{*}{$\begin{array}{l}\text { DEPENDENT } \\
\text { VARIABLE } \\
\text { result } \\
\end{array}$} \\
\hline & sub-criteria & value & \\
\hline \multirow{3}{*}{$\begin{array}{l}\text { Have end states (mission } \\
\text { and goals) of an allied } \\
\text { Unified Protector crisis } \\
\text { response operation been } \\
\text { achieved? }\end{array}$} & legitimacy & YES & \multirow[b]{3}{*}{ YES } \\
\hline & mission of operation & YES & \\
\hline & $\begin{array}{l}\text { goal of operation } \\
\text { (political, military, } \\
\text { humanitarian) } \\
\end{array}$ & YES & \\
\hline \multirow{2}{*}{$\begin{array}{l}\text { Has a concept of } \\
\text { activities carried out } \\
\text { under an operation in } \\
\text { Libya been effectively } \\
\text { applied to a situation? }\end{array}$} & planning process & YES & \multirow[b]{2}{*}{ YES } \\
\hline & selection of component & YES & \\
\hline \multirow{3}{*}{$\begin{array}{l}\text { Have the organisational } \\
\text { structure and potential } \\
\text { used in this operation } \\
\text { been adequate to lead in } \\
\text { Libya activities? }\end{array}$} & organizational structure & YES & \multirow[b]{3}{*}{ YES } \\
\hline & potential & YES & \\
\hline & targeting & YES & \\
\hline \multirow{2}{*}{$\begin{array}{l}\text { Have tactics used in that } \\
\text { operation contributed } \\
\text { to the end states of an } \\
\text { operation? }\end{array}$} & effectiveness & YES & \multirow[b]{2}{*}{ YES } \\
\hline & mileage (phases) & YES & \\
\hline
\end{tabular}

Source: own.

Table 2. An evaluation matrix of the allied Unified Protector crisis response operations

A first general question: Have end states (mission and goals) of an allied Unified Protector crisis response operation been achieved? In this part, information about an operation in Libya was analysed based on the following sub-criteria: legitimacy, the mission and goals of that operation.

The mission of the allied Unified Protector crisis response operation in Libya was concerned with ensuring safety to civilians and to support Libyan rebels at war with a dictator's army. Considering the resolution, which is a mandate of this operation, the following military goals can be distinguished: 1) to ensure the embargo on supplying arms to Libya in the Mediterranean is observed, 2) to enforce a no-fly zone, and 3) to conduct attacks from sea and air on loyal Gaddafi forces who were offending by attacking civilians ${ }^{32}$. A political objective of that

32 See in: UN Security Council Resolution 1973 (2011), adopted by the Security Council at its 6498th meeting, on 17 March 2011, S/RES/1973 (2011). 
operation was to ensure protection for Libyan civilians and areas inhabited by them. Overthrowing Gaddafi wasn't the official goal of these operations but it was rightly argued that Libya would not effectively be at peace if Gaddafi remained the president of the country, so unofficially his overthrow was considered to be a goal of this operation.

To conclude the discussion about the end state of the allied crisis response operation in Libya, it should be considered that the mission and goals resulting from the mandate of this operation were achieved. This operation ended with the overthrow of M. Gaddafi after a rule of over forty years, safety for civilians was certain and the operation was conducted without civilian casualties. This activity was consistent with international law, because multinational forces were operated by a mandate of the UN Security Council (Resolution No 1970 and 1973), which also gave international legitimacy to that operation.

A second general question: Has the concept of activities carried out under the operation in Libya been effectively applied to the situation? In this part, information about the operation in Libya was analysed based on the following sub-criteria: the planning process and the selection of component.

The operational planning process of the allied Unified Protector crisis response operation in Libya was carried out in a few weeks ${ }^{33}$. The North Atlantic Council decided to take over command of the operation in Libya. In the decision process, this institution was guided by the following assumptions: a sound legal basis, strong regional support and a demonstrated need ${ }^{34}$. All the assumptions were complied with. The operation was carried out in accordance with international law, had a mandate - UN Security Council Resolution No 1970 and 1973, and was carried out in cooperation with a regional organisation, the African Union or the League of Arab States. The basis for preparing and conducting that activity was the unwillingness of the Gaddafi regime to cooperate.

33 E. Quintana, The War from the Air [w:] A. Johnson, S. Mueen, Short War, Long Shadow. The political and military legacies of the 2011 Libya Campaign, The Royal United Services Institute for Defence and Security Studies 2012, p. 31.

34 T.E. Book, NATO's Air War in Libya: A Template for future American operations, Fort Leavenworth, Kansas 2012-01, p. 64. 
NATO has not yet interested the African region in the second phase of the planning process, a political and military assessment, and has been creating a database of information on that continent. This base was used to prepare probable variants of the operation in Libya. In that phase, particular attention was paid to the geopolitical situation in this country and region. Libya has access to the sea. Partisans had a motivation to fight, but they did not carry out military training and didn't have weapons. Analysis of these and other factors led to Allied planners preparing a concept of operation based on air and sea components supported by allied Special Forces. Their tasks were to train and help Libyan partisans in war and also to enforce a no-fly zone and arms embargo on Libya.

In conclusion, it should be noted that the concept was effectively applied to a situation in the theatre of operation. The operational planning of the allied operation in Libya showed that NATO was able to develop an effective concept of operation in a limited-time and was able to take on effective action in order to quickly respond to an occurring crisis situation. The analysis of difficult factors (e.g. geography, political situation in the region and motivation of Libyan partisans) led NATO planners to prepare a concept of operation based on air and sea components supported by allied Special Forces. Their tasks were to train and help the Libyan partisans in war and also to enforce a no-fly zone and to impose an embargo on Libya.

A third general question: Have the organisational structure and potential used in this operation been adequate for Libyan activities? In this part, information about the operation in Libya was analysed based on the following sub-criteria: organisational structure, potential and targeting.

The political leadership of the allied Unified Protector crisis response operation in Libya was taken by the North Atlantic Council. The military leadership was held by the Supreme Headquarters Allied Power Europe (SHAPE) through the Allied Joint Force Command (JFC) developed in Naples ${ }^{35}$. Joint Force Command Naples (JFC-Naples), in charge of the operation, was not properly equipped for an actual crisis of this dimension, but managed to improvise on a large scale ${ }^{36}$. Despite these difficulties, it discharged the tasks entrusted to it by using all available means.

35 NATO and Libya..., op. cit.

36 F. Gaub, The North Atlantic Treaty Organization and Libya:.., op. cit., p. viii. 
Allied Forces consisted of air and sea components and Special Forces units. About 8000 soldiers, more than 2600 aircraft (bomber fighters, air refueling aircraft, reconnaissance aircraft, unmanned aircraft flying and helicopters) and more than 21 marine vessels (supply ships, frigates, destroyers, submarines, amphibious assault ships and aircraft ships) were involved from $16^{37}$ NATO member states and cooperating countries. This operation was characterised by the limited commitment of U.S. forces ${ }^{38}$. The United States forces facilitated diagnosis tasks (including unmanned aircraft flying), Special Forces units and air refueling aircraft (about 50 types of $\mathrm{KC}-135 \mathrm{~s}$ and $\mathrm{KC}-10 \mathrm{~s}^{39}$ ). The remaining part of military capabilities was taken by France, the United Kingdom (two thirds of the total) and Italy, Canada, Denmark, Norway, Sweden and Belgium. A supporting role for French, British and American air forces was exercised by components from the United Arab Emirates, Qatar ${ }^{40}$ and Jordan ${ }^{41}$. Their tasks were to enforce a nofly zone (Jordanian Air Force) and bomb ground targets (Air Force of Qatar and UAE).

The operation in Libya is one example from NATO's history of activities carried out using only a precision-guided weapon. During the operation in Libya, 17,939 flights of armed agents took place, which accounted for about 70 per cent of their total number. About 7,642 attacks were air-to-ground attacks using: 3,644 laser-guided bombs (GBU-12, GBU-24), 2,844 bombs guided by navigation devices (GBU-31, GBU-38) and attacks using 1,150 pieces of precision-guided munitions (AGM-114 Hellfire and HOT anti-tank missiles) ${ }^{42}$. These weapons were additionally equipped with GPS systems which ensured effective bombing

37 Belgium, Canada, Denmark, France, Greece, Italy, Jordan, Netherlands, Norway, Qatar, Spain, Sweden, Turkey, United Arab Emirates, United Kingdom and United States. Noted by the author.

38 See in: Libya: Operation Odyssey Dawn (OOD). Executive Summary, Report z 21 September 2011, Joint and Coalition Operational Analysis (JCOA), p. 17.

39 See. T. P. Sheridan, NATO in Libya: Implications on the Future of the Alliance, United States Army War College, Philadelphia 2012, s. 7.

40 Qatar to participate in Operation Unified Protector separated two thirds of the twelve owned military aircraft. See in: E. Quintana, The War from the Air [w:] A. Johnson, S. Mueen, Short War,..., op. cit., p. 32.

41 See in: F. Gaub, The North Atlantic Treaty Organization and Libya: Reviewing operation Unified Protector, Strategic Study Institute U.S. Army War College, Carlisle, PA, 2013, p. 7.

42 M. Gałązka, Targeting w operacji libijskiej, KWARTALNIK BELLONA Nr 4/2012 (671), Wojskowy Instytut Wydawniczy, Warszawa 2012, p. 136. 
from 20000 feet and, when there were bullets which missed the target area, this was limited to 5 metres away from the target ${ }^{43}$.

The activities carried out in Libya were based on the particular bombardment of objects from the air, so an important role was played by the process of targeting. As part of the selection of objects to hit, command teams focused on choosing objectives including the Libyan air defence command and the logistical infrastructure used by Gaddafi's forces. Each object was entered in a list of targets and subjected to detailed analysis, because one of the main goals was to minimise civilian casualties. The opinion of the pilots was that the process took too much time, so consequently this process hindered the bombing.

In conclusion, it should be noted that the organisational structure and potential used during the Unified Protector operation was adequate for the actions carried out in Libya. During this operation, a new generation of military technology (precision-guided weapons) was used, which contributed to the destruction of impact objects (e.g. the Libyan air defence system, the system of command and military infrastructure facilities) without civilian casualties. The air and sea components complied with their tasks. Thanks to the efforts of allied naval forces, eight ships attempting to carry weapons to Libya were stopped. The command structure, in spite of missing equipment, managed the forces effectively. To conclude, the structure and potential were considered to be relative to the actions carried out during the operation in Libya.

A fourth general question: Have the tactics used in that operation contributed to the end states of the operation? In this part, information about the operation in Libya was analysed based on the following sub-criteria: effectiveness and mileage (phase).

The operation in Libya was carried out in three phases. The first phase of that operation started during the Civil War. While the policy of repression was intensified, the Libyan operation passed to the second phase. The coalition forces (Britain, France and the United States) launched an air operation, Odyssey Dawn, in the middle of March 2011. During several days of activities they gained control

43 See in: E. Quintana, The War from the Air [w:] A. Johnson, S. Mueen, Short War,.., op. cit., p. 34. 
of the air by entering the no-fly zone. The U.S. authorities decided to transfer responsibility for ongoing activities to NATO. Officially, on 31 March 2011, NATO took command and started the Unified Protector operation ${ }^{44}$ changing to the third phase of operation. A list of objects to hit covered, inter alia: Libyan anti-air defence (e.g. radar systems), the Libyan system of command and military positions, allied with the dictator, spread around Tripoli and Misrata.

In the first phase of that operation (February - March 2013), the Member States of NATO and allied countries carried out activities mainly related to the evacuation of the population from areas of fighting ${ }^{45}$. The dictator (M. Gaddafi) followed the line that he did not cooperate with the international community, so this situation had disposed them to intensify their activities. Under Resolution No 1973, adopted by the UN Security Council on 19 March 2011, coalition forces launched the air operation, Odyssey Dawn. American, British and French air forces focused on the bombing of Libyan air defences, airfields and military aviation. On the first night, British and American air forces carried out air strikes against airports and military bases spread around Tripoli and Misrata and, during the day, a French aircraft bombed tanks, armoured vehicles and the enemy artillery spread around Benghazi ${ }^{46}$.

The introduction of no-fly zone led the U.S. authorities to transfer command of ongoing activities to NATO. On 31 March 2011, NATO formally took command and started the Unified Protector operation. The foreign ministers of NATO member states and countries committed themselves to cooperate in accordance with the provisions of UNSCR 1970 and 1973 and conduct operations in Libya until: 1) all attacks on civilians and its inhabited territories ceased, 2) forces and

44 See in:magnum-x.pl/index.php?option=com_content\&view=article\&id=1532catid=1 \&Itemid=11 - data pobrania: 08.01.2012.

45 According to the international organisation, UNICEF, less than a month after the first outbreak of fighting in Benghazi, 227000 people fled the country (dating from 9 March 2011). They headed mainly to Tunisia and Egypt. In the next two months, the number of refugees increased to about 600000 people. This information was contained in the report dated 13 May 2011 issued by the UN Office for the United Nations Office for the Coordination of Humanitarian Affairs (UN-OCHA). It testifies to the fact that about 1240 Libyans escaped on 13 May 2011 and sailed the Mediterranean on boats and reached the Italian island of Lampedusa. See in: D. Brążkiewicz, Wojna domowa w Libii..., op. cit., p. 150.

46 See in: Ibidem, p. 149. 
mercenaries loyal to the dictator withdrew from occupied territory; 3) Libyan authorities allowed humanitarian aid to Libyan society ${ }^{47}$.

An Allied Maritime Component supported by the Air Forces focused on patrolling the Libyan sea border and an air component focused on enforcing a no-fly zone over Libya. Allied air forces, on the provision of partisans, led the bombing of designated military and civilian facilities (in case they were used by forces allied with the dictator). A list of targets included coastal and inland cities (e.g.: Tripoli, Misrata, Sutra, Suntan), located deep in the country's military bases, ammunition magazines, command centres, government buildings, military barracks, air defence systems and Libyan military capabilities (e.g. tanks, rocket launchers ), etc. ${ }^{48}$. The list of targets also included Libyan naval forces. For example, on $19-20$ May 2011 eight Libyan warships were sunk ${ }^{49}$.

To conclude the discussion of tactics, it was found that the tactics used in this action contributed to end states of the operation. The allied Unified Protector crisis response operation ended on 31 October 2011. During this action, air forces made more than 26,100 sorties and allied warships inspected more than 3000 ships, stopping 11 vessels off the Libyan coast suspected of non-compliance with the embargo on weapons. The air force destroyed the command system of the Libyan armed forces, many military magazines with ammunition and military airports. Taking the statistical data into account, it should be considered that the operation in Libya is an example of activities which were carried out effectively.

\section{Summary}

To quote M. Marszalek, the increasing role of crisis response operations in preventing and responding to various crisis situations should be noted, and, consequently, the need for a reliable evaluation of them based on scientific

47 See in: B. Wysota, Operacja militarna NATO w Libii a koncepcja odpowiedzialności za ochronę, ZESZYTY DOKTORANCKIE WBN, Kwartalnik nr 1(2) 2012, AON, Warszawa 2012, p. 43.

48 See in: Ibidem, p. 44.

49 See in: D. Brążkiewicz, Wojna domowa w Libii..., op. cit., p. 154. 
methods ${ }^{50}$, which should have a significant impact on improving the process of preparing and conducting future operations. Carried out properly it should be based on an analysis of collected material in terms of the criteria generated by specific methods. There are many methods for determining the criteria. The author applied an organisational approach based on Leavitt's model and operational factors determined the operational planning process. Using these methods, the author selected the following criteria: mission and goals, concept, organisational structure and potential, and also tactics.

The generated criteria were used to retrospectively evaluate the Allied Unified Protector crisis response operation in Libya. Furthermore, in order to effectively prepare the evaluation, the author used an evaluation matrix. Using this matrix made it possible to conduct an effective assessment of the Allied Unified Protector operation. Having evaluated the allied crisis response operation in Libya, it seems to be correct to conclude that an evaluation of current operations should contribute to preparing an effective operational planning process of future activities. The operation in Libya is a testament to the organisational process of these actions which benefitted from the experience of previous crisis response operations: Allied Force in Kosovo and Enduring Freedom in Afghanistan, and, so, consequently paved the way for achieving the main goal of operations, i.e. the security of the civilian population and its inhabited sites. Moreover, according to the evaluation matrix of the operation in Libya, this action can be considered as a model example of future crisis response operations conducted by NATO.

To conclude finally, the use of evaluation methods paved the way for preparing an effective assessment of operations. This process is needed to determine whether it was completed successfully or outlined to forecast future crisis response operations.

50 M. Marszałek, Dylematy..., op. cit., p. 199. 


\section{Bibliography}

1. Allied Joint Publication 3.4., Non-Article 5 Crisis Response Operations, NATO/NAS Brussels 2005.

2. Bieniek M., Kategorie operacji pokojowych. Czynniki wptywajace na zaangażowanie Polski w operacje pokojowe, [w:] E. Trela - Mazur (red.), Problemy bezpieczeństwa wspótczesnego świata, Uniwersytet Opolski, Opole 2009.

3. Book T. E., NATO's Air War in Libya: A Template for future American operations, Fort Leavenworth, Kansas 2012-01.

4. Brążkiewicz D., Wojna domowa w Libii w 2011 roku, KWARTALNIK BELLONA, Ministerstwo Obrony Narodowej, Rocznik XCIV (VI), Nr 4/2012 (671), Warszawa 2012.

5. Denysiuk I., Osypowicz M., Istota i założenia oceny operacji reagowania kryzysowego [w:] Kopczewski M., Grzelczak-Miłoś I., Walachowska M., Paradygmaty badań nad bezpieczeństwem. Zarzadzanie kryzysowe w teorii i praktyce, Wydawnictwo Wyższej Szkoły Bezpieczeństwa, Poznań 2013.

6. Gałązka M., Targeting $w$ operacji libijskiej, KWARTALNIK BELLONA Nr 4/2012 (671), Wojskowy Instytut Wydawniczy, Warszawa 2012.

7. Gaub F., The North Atlantic Treaty Organization and Libya: Reviewing operation Unified Protector, Strategic Study Institute U.S. Army War College, Carlisle, PA, 2013.

8. http://www.pte.org.pl/x.php/1,155/O-ewaluacji.html

9. Krzyżanowski L. J., O podstawach kierowania organizacjami inaczej: paradygmaty, modele, metafory, filozofia, metodologia, dylematy, trendy, Wydawnictwo Naukowe PWN, Warszawa 1999.

10. Libya: Operation Odyssey Dawn (OOD). Executive Summary, Raport z 21 września 2011 roku, Joint and Coalition Operational Analysis (JCOA).

11. magnum-x.pl/index.php?option=com_content\&view=article\&id=1532catid=1\&Ite $\operatorname{mid}=11$

12. Marszałek M., Dylematy ewaluacji operacji wsparcia pokoju [w:] Sienkiewicz P., Marszałek M., Świeboda H. (red. nauk.), Metodologia badań bezpieczeństwa narodowego. Bezpieczeństwo 2010, t. II, AON, Warszawa 2011.

13. Marszałek M., Interwencja humanitarna - typologia, kryteria sukcesu, „Zeszyty Naukowe AON", nr 3(76)/2009.

14. NATO - News: „We answered the call” - the end of Operation Unified Protector, http:// www.nato.int/cps/en/SID-60209894-E985CD49/natolive/news_80435.htm

15. North Atlantic Treaty, Washington, the 4th of April 1949.

16. Operation UNIFIED PROTECTOR Final Mission Stats 02 November 2011; pdf. 
17. Osypowicz M.,Zastosowanie operacji reagowania kryzysowego w systemie zarzadzania kryzysowego NATO, I Konferencja Młodych Naukowców Bezpieczeństwo narodowe i międzynarodowe wobec wyzwań wspótczesnego świata, 17 kwietnia 2013 r., AON, monografia w druku;

18. Quintana E., The War from the Air [w:] Johnson A., Mueen S., Short War, Long Shadow. The political and military legacies of the 2011 Libya Campaign, The Royal United Services Institute for Defence and Security Studies 2012.

19. Sheridan T. P., NATO in Libya: Implications on the Future of the Alliance, United States Army War College, Philadelphia 2012.

20. Sienkiewicz P., Teoria efektywności systemów, Wydawnictwo Polskiej Akademii Nauk, Wrocław, Warszawa, Kraków, Gdańsk, Łódź, 1987.

21. UN Security Council Resolution 1970 (2011), adopted by the Security Council at its 6491th meeting, on 26 February 2011, S/RES/1970 (2011).

22. UN Security Council Resolution 1973 (2011), adopted by the Security Council at its 6498th meeting, on 17 March 2011, S/RES/1973 (2011).

23. Wysota B., Operacja militarna NATO w Libii a koncepcja odpowiedzialności za ochronę, ZESZYTY DOKTORANCKIE WBN, Kwartalnik nr 1(2) 2012, AON, Warszawa 2012. 